\title{
DYNAMIC CLIMATOLOGIC PROCESSES OF BAROMETRIC CAVE SYSTEMS USING THE EXAMPLE OF JEWEL CAVE AND WIND CAVE IN SOUTH DAKOTA, USA
}

\author{
DINAMIKA KLIMATOLOŠKIH PROCESOV V BAROMETRIČNIH \\ JAMAH: PRIMER JAM JEWEL CAVE IN WIND CAVE V JUŽNI \\ DAKOTI, ZDA
}

\author{
Andreas PFLITSCH ${ }^{1}$, Mike WILES ${ }^{2}$, Rodney HORROCKS ${ }^{3}$, Jacek PIASECKI ${ }^{4} \& J^{\prime}$ lia RINGEIS ${ }^{1}$
}

\begin{abstract}
UDC 551.581:551.44(78)

Andreas Pflitsch, Mike Wiles, Rodney Horrock, Jacek Piasecki \& Julia Ringeis: Dynamic climatologic processes of barometric cave systems using the example of Jewel Cave and Wind Cave in South Dakota, USA

Jewel and Wind Cave are two big barometric cave systems in South Dakota, USA. The entrances of Jewel and Wind Cave are roughly $50 \mathrm{~km}$ apart, and until now it is unknown whether their entrances belong to two separate caves or to one much larger cave system. One possibility for testing these two competing hypotheses is to measure and analyse the climatic conditions in the vicinity of these entrances and within the caves in detail. In this context, the thermal conditions and air currents are crucial. These in turn can be characterised by the spatial and temporal patterns of the dynamics of air entering and leaving through the respective entrances; even though these dynamics are coupled to atmospheric pressure fluctuations outside the caves, they differ for different cave systems and provide a "fingerprint" that has implications for the size and structure of individual cave systems. To give an example, Jewel and Wind Cave as the second and fourth-largest cave systems on earth show some similarities, but many more noticeable differences regarding their climatological behaviour, despite their close proximity to each other. The last big measurement campaigns on the climatic systems of the two barometric caves were carried out by Herb and Jan Conn in the 1960s, (Conn 1966). Despite their elementary work, the technical possibilities were very limited in those days. The self-constructed mechanical measurement equipment could only be used for basic measurements. Herb Conn was still able to identify the basic mechanism very clearly. He also carried out a number of different calculations on barometric air flow that remain important
\end{abstract}

\begin{abstract}
Izvleček UDK 551.581:551.44(78)
Andreas Pflitsch, Mike Wiles, Rodney Horrock, Jacek Piasecki \& Julia Ringeis: Dinamika klimatoloških procesov $v$ barometričnih jamah: primer jam Jewel Cave in Wind Cave v Južni Dakoti, ZDA
\end{abstract}

Jewel Cave in Wind Cave sta velika barometrična jamska sistema v Južni Dakoti, ZDA. Vhoda v jami sta med seboj oddaljena približno $50 \mathrm{~km}$. Trenutno še ne vemo, če sta jami povezani $\mathrm{v}$ en velik sistem oziroma če sta povsem ločeni. Obe hipotezi bi lahko posredno preverili s sočasnim opazovanjem in analizo klimatskih parametrov na več točkah v jamah. Gibanje zraka v barometričnih sistemih vsiljujejo spremembe zračnega tlaka na površju. Po drugi strani krivulja hitrosti vetra oblikuje vzorec, ki je za vsako jamo značilen in odvisen od njene velikosti in geometrije. Jewel Cave in Wind Cave kažeta podobne vzorce, a so med njimi pomembne razlike. Herb in Jan Conn sta $\mathrm{v}$ šestdesetih opravila niz meritev $\mathrm{z}$ enostavno, doma narejeno opremo. Vseeno sta iz podatkov izluščila osnovne klimatske mehanizme v obeh jamah. Novejši razvoj ultrazvočnih anemometrov in ostale merilne tehnike, nam je omogočil sočasne, natančne in zvezne meritve na več mestih. Nove meritve, ki potekajo od leta 2001, nam omogočajo natančno obravnavo razlik časovnih vrst $\mathrm{v}$ kontekstu geometrije in povezanosti obeh jam.

Ključne besede: barometrične jame, jamska klima, Jewel Cave, Wind Cave, Black Hills.

\footnotetext{
${ }^{1}$ (corresponding author) Ruhr-Universität Bochum, Geographisches Institut, 44780 Bochum, e-mail: andreas.pflitsch@rub.de

${ }^{2}$ Jewel Cave National Monument, 11149 US Highway 16 \#B12, Custer, SD 57730, USA, e-mail: Mike_Wiles@nps.gov

${ }^{3}$ Wind Cave National Park, 26611 US HWY 385, Hot Springs, SD 57747, USA, e-mail: Rod_Horrocks@nps.gov

${ }^{4}$ Department of Meteorology and Climatology, Institute of Gegraphy \& Regional Development, University of Wrocław, pl. Uniwersitecky 1, 50-137 Wrocław, Poland, e-mail: piasecki@biskupin.wroc.pl
}

Received/Prejeto: 04.03.2010 
up to the present day. During the last 40 years, rapid electronic development has enabled us to use instruments that are far more precise and sensitive. The use of ultrasonic anemometers and dataloggers enables us to take more exact long term measurements. An extensive measurement programme was started in 2001 to fulfil several research aims, and we are now in a position to decipher the different fingerprints of the caves much more reliably.

Keywords: barometric cave, cave climate, Jewel Cave, Wind Cave, Black Hills.

\section{INTRODUCTION \& AIMS}

Jewel and Wind Cave are two big cave systems in South Dakota, USA. Compared to the majority of caves where air flow is caused by temperature differences between the outside atmosphere and the air inside the cave, Wind and Jewel Cave are so-called barometric caves. The air flow of caves of this type is a result of atmospheric air pressure changes.

Since the discovery of Wind and Jewel Cave and up to today the extent of the cave system is still unknown.

have shown that at present only 10 to $20 \%$ of the total volume of the caves is known.

The entrances of Jewel and Wind Cave are roughly $50 \mathrm{~km}$ apart from each other, yet the question remains as to whether these are two separate cave systems or form a single cave system. The most recent examinations show that close-by smaller (a few kilometres long) cave systems (Jasper Cave, S \& G Cave, Coyote Cave \& Reeds Cave) have the typical features of barometric caves (Fig. 1). Those caves

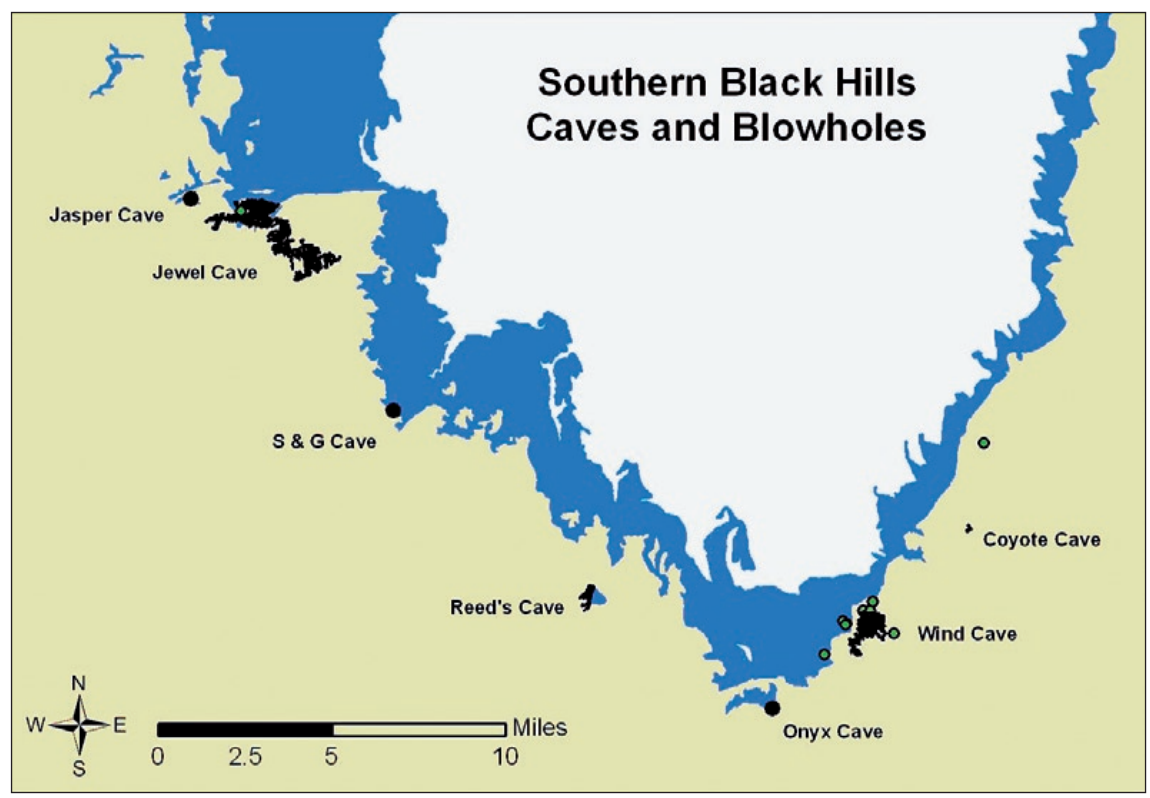

Fig. 1: Overview of the location of Jewel Cave and Wind Cave compared to different smaller caves (black dots and marks) and blow holes (green dots) showing the characteristic air flow pattern of barometric caves within the Southern Black Hills (South Dakota, USA). Brown: Madison Formation, blue: Minnelusa Formation.

There are weekly survey-trips by the national park, cave clubs and interested people, to discover, measure and map the caves' extent. Climatologic measurements and volume analysis based on the theory of Conn (1966) (known parts) are far too small to have typical features of a barometric cave system, which leads to the speculation that the several smaller caves are attached to the two big caves, maybe forming one massive cave system.

Due to the geological conditions, this discussion cannot be solved, particularly because of the great distance of $50 \mathrm{~km}$ between those parts of the caves which are currently located closest to each other. Based on the current state of knowledge, the discovery of a direct connection in the coming centuries is very unlikely. Therefore climatological research is aiming to find a solution to this question.

The question of the basic air flow mechanisms in barometric caves and the full size of both caves are the main aspects of a research project from the cave- and subway-climatology working group at the Ruhr-University of Bochum (Germany) (Pflitsch et al. 2007). 


\section{THEORETICAL CONSIDERATIONS}

In the following different theoretical considerations concerning the driving forces, characteristics and functioning of air flow in barometric caves are discussed and contrasted with the air flow in thermal caves. We consider this useful because discussions at several conferences have shown that often not much is known about the climatology of barometric caves, and also research indicates that the mechanisms and air flow characteristics in barometric caves are more complex than expected at first. So it seems worthwhile to promote scientific discussion in this field.

\section{GENESIS OF AIR FLOW IN BAROMETRIC CAVES}

Within barometric caves thermal mechanisms that would lead to different air pressures or an unequal pressure balance are very small compared to the air currents within the cave that are a result of air pressure differences be-

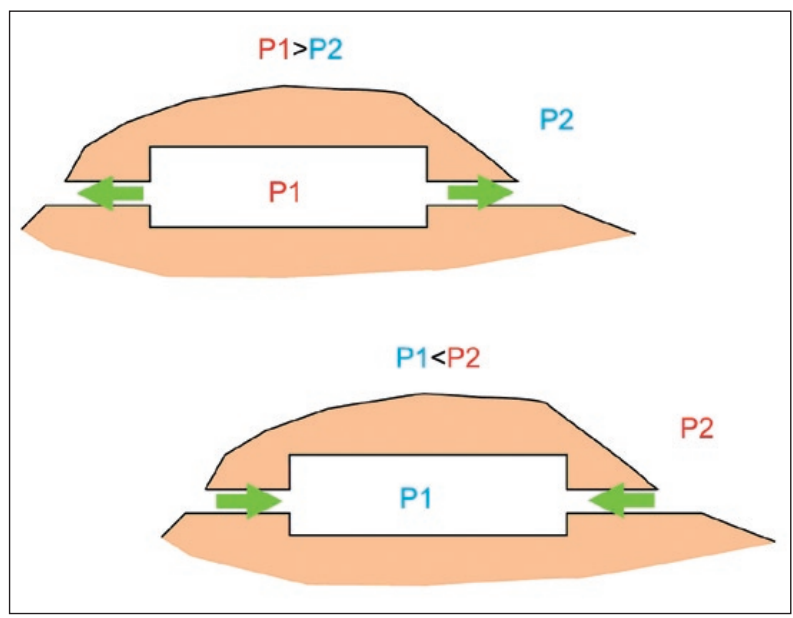

Fig. 2: Schematic overview of the functioning of barometric cave systems. P1: air pressure inside the cave, P2: outside air pressure.

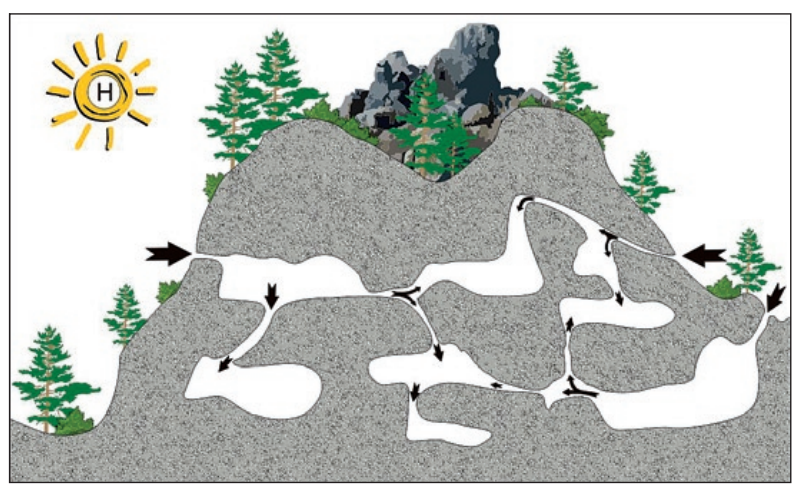

Fig. 3: Schematic representation of the air flow situation in a barometric cave system at high pressure $(H=$ area of high pressure) in the outer atmosphere, and air flow into the cave. tween the cave weather and the outside atmosphere (see Fig. 2).

Air pressure variations in the outer atmosphere usually enter a cave system quite quickly through its openings. Increasing air pressure leads to a rising pressure inside the cave; falling air pressure outside leads to a decrease of pressure within the cave. Short-term air pressure differences between the outer atmosphere and cave, as well as air pressure exchange, are not or hardly measurable in most cave systems. This holds especially true for small and middle-sized cave systems, which either have a high number of openings or caves with a few small openings where quick air exchange is not possible. Even big cave systems with big openings show a quick air pressure exchange, but the air flow is mostly not detectable.

The situation is different for cave systems with an entrance that has a small cross section, compared to the size and volume of the cave behind the opening. The air exchange is restricted, and a quick air pressure equalisation is not possible. This can be explained as follows:

Starting with an equal air pressure between the cave and outer atmosphere, there is no equilibrating air flow. If a high pressure system exists, the air pressure is rising outside the cave, and an air pressure difference between the cave and outer atmosphere arises. If the relation between the cave entrance and the cave volume is not favourable, a direct adjustment of air pressure will be impossible and, as a result of this, a relative over-pressure occurs outside the cave. This pressure difference - with a relative under-pressure within the cave - leads to equilibrating air flow into the cave. This continues until an equilibrium situation is reached (Fig. 3). If air pressure is still rising, the pressure difference rises too, and the air flow increases as a consequence.

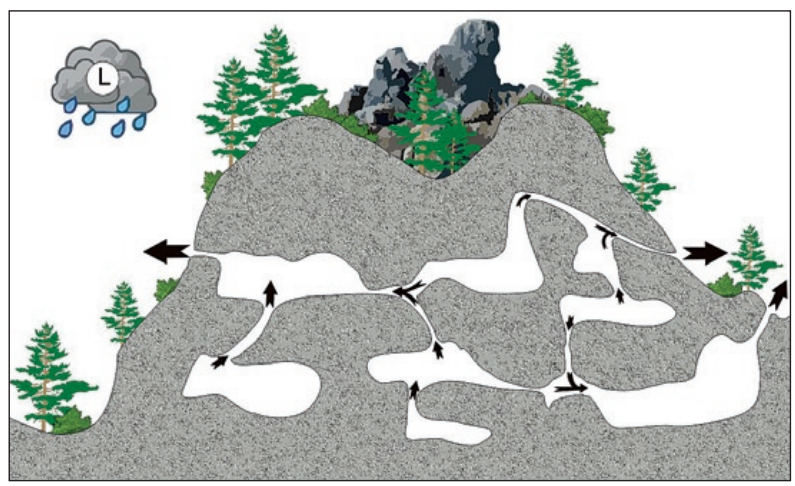

Fig. 4: Schematic representation of the air flow situation in a barometric cave system at low pressure $(T=$ area of low pressure) in the outer atmosphere, and air flow out of the cave. 
If the air pressure outside the cave is falling again, the pressure difference between both systems decreases, and the air flow speed decreases. In case these relations are equal, air exchange stops. If the air pressure keeps falling, a higher pressure within the cave compared to that outside will result in the air flow being reversed from the cave to the outer atmosphere (Fig. 4). This process lasts as long as either enough air has flowed out of the cave (i.e. an equilibrium situation has been reached) or until the air pressure outside rises again.

Fig. 5 shows some air flow measurements of the Historic Entrance of Jewel Cave and pressure readings in one of the office buildings a few hundred meters away bulence of the air flow, are responsible for the duration and strength of the air exchange. Especially long-lasting or very quick changes in air pressure result in a rapidly rising pressure difference between cave air and the outer atmosphere. This leads to long-lasting and intense compensating air flow.

If the cave structure represents one big unit, with wide corridors and halls, the compensating air flow can only be detected near the openings. If the cave structure is strongly jointed with several different parts, which are separated by narrow passageways and tunnels, compensating air flows are detectable in many parts of the cave system. In general, the first characteristic is found at Wind Cave and the second at Jewel Cave.

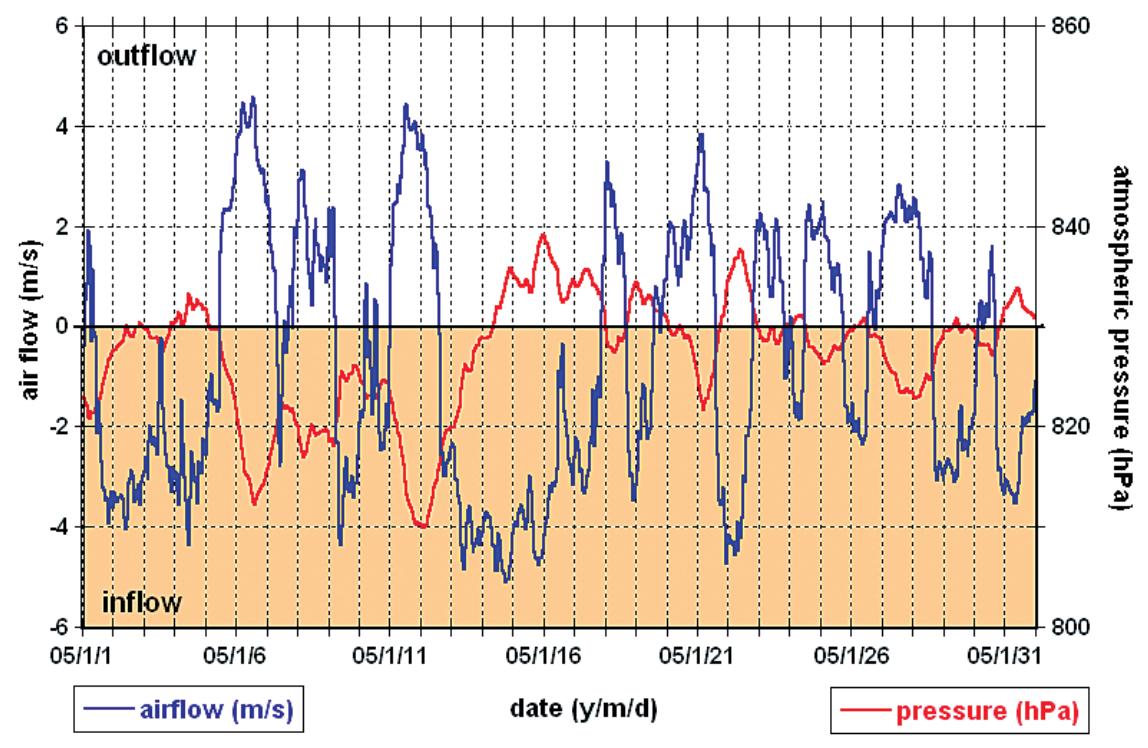

Fig. 5: Course of air flow direction and velocity at the Historic Entrance of Jewel Cave, as well as air pressure in the administration building at Jewel Cave NM. Measured from 1-31 January 2005 with an ultrasonic anemometer (10 $\mathrm{Hz}$ and averaging time of $10 \mathrm{~s}$ ).

from the entrance area. The above-explained processes are clearly visible.

Passing and stationary pressure systems are macroscale features with meso-scale variations and not microclimatical phenomena. Therefore they influence a whole region and the whole cave system. The compensating air flow takes place at all cave openings at the same time. Rising air pressure outside means air flow into the cave; falling air pressure outside means air flow out of the cave. It is of no importance how many openings a cave has. The important factor is the relation of cave volume to the width of the cave openings. The more the disparity between these factors, the more the compensational effects are noticeable and measurable.

Furthermore, the cave structure and the macro and micro structures of the walls, which affect the tur-

\section{THERMAL VS. BAROMETRIC CAVES}

The climatologic differences of both cave types are mainly based on the different driving forces of air flow that occur in the entrance area and also in the interior of the cave. In thermal caves density differences of unequal tempered air masses lead to compensating air flows (Moore \& Sullivan 1964; Bögli 1978), while in barometric caves pressure variations of the atmosphere enforce a temperature independent compensating air flow (Palmer 2007; Pflitsch et al. 2007). The different genesis of air flows has farreaching consequences for the climatologic character of the caves, which is explained in the following.

The most important differences between thermal ${ }^{1}$ and barometric caves concerning the character of the air flows are:

- Strength of compensating air flow. Even though there are some large caves with wide conduits and very strong chimney effects (maxima around $5 \mathrm{~m} / \mathrm{s}$, average around $1 \mathrm{~m} / \mathrm{s}$ ), the air flow velocity in many caves of this type is

\footnotetext{
${ }^{1}$ The statements made in this article on thermal caves apply only to dynamic caves with two openings at different elevations above sea level. In static caves like "Sackhöhlen" or for example the Schellenberger Ice Cave (Germany) or Monlesi Ice Cave (Switzerland) different processes take place (Luetscher \& Jeannin 2004).
} 
rather low (maxima $<0.5 \mathrm{~m} / \mathrm{s}$ or just $<0.2 \mathrm{~m} / \mathrm{s}$ ) (Pflitsch and Piasecki 2003). Within barometric caves air flow of several $\mathrm{m} / \mathrm{s}$ can be measured, at least close to the openings, and sometimes within the cave.

- Variability in time. The compensating air flow within thermal caves mainly has a strong seasonal characteristic, with clear differences between summer and winter and stronger oscillations of direction during spring and autumn. Barometric caves show small differences between summer and winter; this effect is due to the seasonal variability and stability of passing pressure systems. The typical changes of direction take place throughout the whole year and show different intervals of a few seconds up to several days.

- Direction of air flow. The most characteristic difference between the two cave types is the direction of air exchange. In an ideal barometric type of cave, air exchange is taking place through all openings and across the whole profile in the same direction (into or out of the cave) at the same time. In contrast to this, air flow into and out of the cave in thermal caves usually takes place at the same time (inflow in one, outflow at another entrance), but through different openings. Caves with just one opening show a vertical differentiation in air exchange.

- Volume vs. pressure change. Another small but important difference is the effect of the inward and outward flowing air on the pressure conditions inside the cave. The pressure drop in thermal caves caused by the outflowing air to the upper entrance in winter and the lower entrance in summer is equalized shortly by air flowing into the other entrance. So, the pressure inside the cave is more or less in equilibrium with the outside pressure at all times (this is an idealised assumption and a theoretical concept). In a barometric cave we have a steady air movement in order to equalize the air pressure with the outer atmosphere, which is never accomplished for longer time periods (see Figs. 12 to 17). In opposition to a thermal cave there is a steady pressure change inside the cave due to the in- or outflowing air. Related to inflow, we also have a temperature as well as a volume or pressure change of the inflowing air in caves of both types. This process and its consequences are described in detail in the following.

In thermal caves with two surface openings at different elevations, in summer the air inside the cave, which is cooler, denser and heavier per $\mathrm{m}^{3}$ compared to the warmer air outside, flows out at the lower located surface opening, and the relatively warm outside air flows through the upper surface opening into the cave (Pflitsch \& Piasecki 2003). The inflowing warm air usually cools down significantly when entering the cave. Solely because of this cooling - changes in density through differences in elevation remain unconsidered here - a definite mass of air becomes denser and accordingly reduces its volume. Thus the specific density of air at $25^{\circ} \mathrm{C}$ (1 atm) is $1.184 \mathrm{~kg} / \mathrm{m}^{3}$, while it increases to $1.269 \mathrm{~kg} / \mathrm{m}^{3}$ at $5^{\circ} \mathrm{C}$. The values are based on typical temperatures as they occur at the entrance area of Jewel Cave in South Dakota in summer and winter, without taking extreme temperatures into account. In return the volume of $1 \mathrm{~m}^{3}$ of air decreases to $0.933 \mathrm{~m}^{3}$ when being cooled down from $25^{\circ} \mathrm{C}(1 \mathrm{~atm})$ to $5^{\circ} \mathrm{C}$. Thus if $1 \mathrm{~m}^{3}$ of air flows out at $T_{\text {outside }}>T_{\text {Cave }}$ (at the lower surface opening) a volume of $>1 \mathrm{~m}^{3}$ will flow into the cave. That should be noticeable by a relatively higher air flow velocity at the upper surface opening ${ }^{2}$.

During the transition from summer to winter this process stops. As soon as $T_{\text {outside }}$ is $<T_{\text {cave }}$ in the area of the lower surface opening the relatively warmer air inside the cave can not flow out anymore but remains inside the cave. If $T_{\text {cave }}$ is $>T_{\text {outside }}$ at the upper surface opening the relatively warm air inside the cave starts to flow into the atmosphere, while at the lower opening colder air from the outside flows $\mathrm{in}^{3}$. That air is warmed up quickly in the cave, expands and becomes less dense. Thus the specific density of an inflowing air mass with a temperature of $-10^{\circ} \mathrm{C}$ is $1.341 \mathrm{~kg} / \mathrm{m}^{3}$, while it decreases to $1.269 \mathrm{~kg} / \mathrm{m}^{3}$ in case of a warming to $5^{\circ} \mathrm{C}$. In return its volume increases to $1.056 \mathrm{~m}^{3}$, thus by $0.056 \mathrm{~m}^{3}$. So, the air volume that enters the cave is smaller than the volume that is lost at the surface opening. Thus, the flow velocity will be higher at the upper surface opening. Adiabatic processes can be neglected when looking at caves of little vertical extension. Based on a vertical rise of $100 \mathrm{~m}$ and an adiabatic cooling of $1 \mathrm{~K}$ the volume would decrease only by $0.003 \mathrm{~m}^{3}$.

In summary it can be said that the direction of air flow as well as the velocity of air flow are a function of the difference in air temperature between the air inside the cave and outside. We do have opposite processes at the entrance at different elevation levels.

In barometric caves on the other hand, the described processes do not exist in the form of a system that is solely generated by differences in temperature, but are being

\footnotetext{
${ }^{2}$ A direct comparison of flow velocities is only possible if the surface openings are identical. As this is almost never the case this can only be verified by calculations.

${ }^{3}$ This process is called the chimney effect in the literature and in this article. However it must be noted that in contrast to a chimney the driving force is neither a source of heat at the ground from where warm air soars up, nor an air flow at the upper surface opening which pulls air out of the cave. It is merely a difference in density of the relatively warmer air inside the cave compared to the air temperature at the upper surface opening.
} 
shaped by barometric processes (Nepstad \& Pisarowicz 1989; Conn 1966). Generated by pressure changes of the outer atmosphere, the processes at each opening are in general the same. Nevertheless the temperature differences between the two air masses are of great importance for the formation of a specific flow pattern in the cave as well as for the exchanged volumes of air. When barometric processes lead to an inflow of warm air into the cave in summer, this air, which is flowing in through all surface openings, is being cooled down as well, experiences an increase in density and accordingly decreases in volume as it enters the cave. The increase in pressure that is caused by the inflowing air becomes quickly smaller in the course of further inflow. Thus, more than the amount of air that originally flowed into the cave has to follow in order to reach pressure equalisation.

For example, an amount of air with a mass of $1 \mathrm{~kg}$ has a volume of $0.844 \mathrm{~m}^{3}$ at $25^{\circ} \mathrm{C}(1 \mathrm{~atm})$. If this is cooled down to $5^{\circ} \mathrm{C}$ the volume decreases to $0.788 \mathrm{~m}^{3}$, and its contribution to pressure rise in the cave will decrease respectively, which enables the additional inflow of air - in this case $0.056 \mathrm{~m}^{3}$ or $7.1 \%$. In winter on the other hand, when cold and dense air flows into the cave an inflowing mass of air is being warmed up and either increases in volume or increases in pressure at the same volume, so that there is a secondary and delayed increase in pressure as a result of the barometric process .

This means that in winter - based on the same conditions regarding the pressure differences - the pressure rise inside the cave is being balanced as much by the barometric determined balancing flow as by the increase in volume and the above described associated pressure rise of the heated air. Even though this process is effective only on a much smaller scale, it should be noticeable and taken into account.

In summer on the other hand, when warm and less dense masses of air move inside, it takes more time for the cooling masses of air to reach pressure equalisation.

For the flow balance this means that in summer a larger volume of air has to flow into the cave than in winter in order to reach the same pressure equalisation (this should not be confused with having a higher amount of air mass flowing into the cave by this effect). This is achieved by higher flow velocities or longer times of inflow for each opening. The consequences for the mass balance should be marginal because the sum of the three variables- flow velocity, air density and flow duration- is the same. These seasonal differences should become clear by means of the measurements. Apart from that, different "behavioural patterns" of various cave systems help to detect structural and thermal differences. In case of a drop in pressure it should be exactly the other way round.
Temperature profile. The above described differences in flow conditions lead to differences regarding the thermal conditions of caves, which will influence especially the temperature profile between the surface openings (thermal cave) and the cave lying behind In the case of thermal caves with at least two surface openings in different elevations, they will influence the whole cave system. From the above mentioned considerations the following temperature patterns can be derived.

Thermal cave, upper surface opening: this opening is influenced by the passing by of relatively warm air masses. In summer, when the air flow mainly leads into the cave, relatively warm air from the outside flows into the cave, while in winter the air from the cave that is warmer than the outside atmosphere flows out of the cave.

Thermal cave, lower surface opening: this opening is characterised by the discharge of cool air masses. In winter the cold air of the outside atmosphere flows into the cave, while in summer the air inside the cave that is relatively cool compared to the outside atmosphere flows out of the cave.

This leads to the formation of a relatively cool area in the lower cave, while the upper parts of a thermal cave are warmer in annual mean. In this respect the thermal vertical gradient of the atmosphere has to be taken into account. This means that the absolute temperature values have to be reduced accordingly in order to be able to note the described effects. The temperature gradient between the two openings should point in the same direction provided that there are no further influences. Thereby the gradients near the opening will be high, and in lots of caves the temperature equilibrium is reached after a few metres, but dependent on the amount of air flow this can vary up to a few hundred metres.

The thermal appearance of barometric caves turns out to be entirely different. At all surface openings there is a constant change between in- and outflowing air throughout the year. Thus in summer relatively warm air (compared to the air inside the cave) and in winter relatively cold air masses penetrate into all openings from the outside. Therefore the temperature gradient observed between the cave openings and the inner parts of the cave should run similarly from every surface opening until in the interior. Our own measurements have shown barometric pressure change-related short term temperature variation more than $2 \mathrm{~km}$ away from the nearest cave opening. The seasonal temperature variations are at all openings the same, a mostly relatively cold inflow in the winter and a mostly relatively warm inflow in the summer. The reach of the temperature variations of the air inside the cave and of the rock surface, coming from the surface openings, should depend 
on the mass and velocity of the infiltrating air. Here the topographic situation of the particular surface openings must be taken into account. Especially during winter, considerably cooler air masses flow in from valleys than from upper hillsides.

The above considerations are useful theoretical concepts, as, apart from showing the different processes at an ideal type of cave, thermal and barometric caves are clearly separated from each other. This clear separation does not exist in reality. Within each cave thermal and barometric generated processes exist side by side. Key factors that influence the most important effects are:

- Cave structure,

- size of the cave,

- relation between cave volume and width of the openings.

Within a thermally distinct cave, the occurrence of barometric processes is relatively small (as far as they are detectable), because the pressure equalisation happens immediately and at all openings at the same time in case of a large width of the openings and/or in small caves.
The identification of thermal processes in barometric caves is mostly difficult as well. Thermally generated air flow is often weaker and not very distinct. Therefore, barometric events are overprinting or overlapping each other more or less intensely. Because thermal effects are different at the different openings it might be easier to detect them. Furthermore, the reasons for several different cause-and-effect connections are harder to put together, as the barometric processes are based on atmospheric air pressure changes.

Nevertheless there is evidence that thermal and barometric effects can exist inside a single cave system and even close to each other, which is described in Boes et al. (1997). For instance in Wind Cave there is a very pronounced chimney effect leading to an almost yearround rise of air. Sporadically occurring events of flow reversal - meaning downward flowing cold air - appear totally independent of the barometric conditions. What is special about this situation is the location of the pit that is only a few meters away from the main opening of Wind Cave, the natural entrance through which a majority of the barometric air exchange happens.

\section{CLIMATOLOGICAL MEASUREMENTS IN THE CAVES OF THE BLACK HILLS, SOUTH DAKOTA, USA}

\section{Details about Jewel Cave and Wind Cave}

Wind and Jewel Cave are part of the Black Hills in South Dakota, USA. Jewel Cave is, with a current known length of $245 \mathrm{~km}$, the second longest cave in the world. Wind Cave is at present estimated as being $200 \mathrm{~km}$ long and is the third longest cave in the world (as of November 2008). Both caves have several openings and blow holes. Some of them have been discovered by the research projects listed below. The so called "Historic Entrance" of Jewel Cave (Figs. $6 \& 7$ ) is located $1614 \mathrm{~m}$ above sea level. The cave's vertical expansion is $134 \mathrm{~m}$. The so called "Natural Entrance" of Wind Cave (Figs. 8 \& 9) is located $1244 \mathrm{~m}$ above sea level, and the vertical extent is $198 \mathrm{~m}$ (National Park Service 2007a, b).

\section{Current measurement programme}

An extensive long-term measurement programme was installed in 2001 to fulfil several research aims. The measurements concentrate on the two big cave systems, Jewel and Wind Cave. The smaller neighbouring caves were added to the measurements during the project as well. The measurements relevant for this report are those of air flow using ultrasonic anemometers (Pflitsch \& Flick 2000) at several measurement points (Figs. 10 \& 11) within the caves and air pressure measurements at different points outside Jewel and Wind Cave, plus short-term measurements at Jewel Cave.

The numerous blow holes surrounding the caves are surface openings which are only a few centimetres in diameter. Here flow measurements via ultrasonic anemometers are not possible. Therefore air temperature was used as an excellent indicator for air flow events. In order to record the air temperature a temperature sensor with integrated data logger was placed inside each blow hole.

A detailed description of the measurement programme can be found in Pflitsch et al. (2007).

\section{Selected results}

The following chapter presents selected measurement results. These show the functioning of a barometric cave system and the classification of the individual cave systems. 


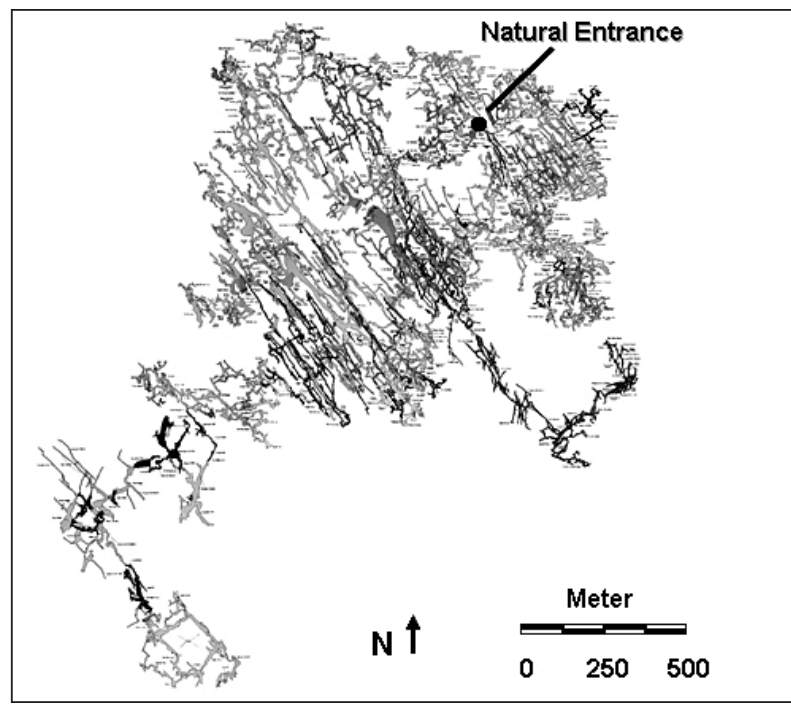

Fig. 6: Outline of Wind Cave, South Dakota (USA). Reference: Wind Cave National Park Service, with own additions.

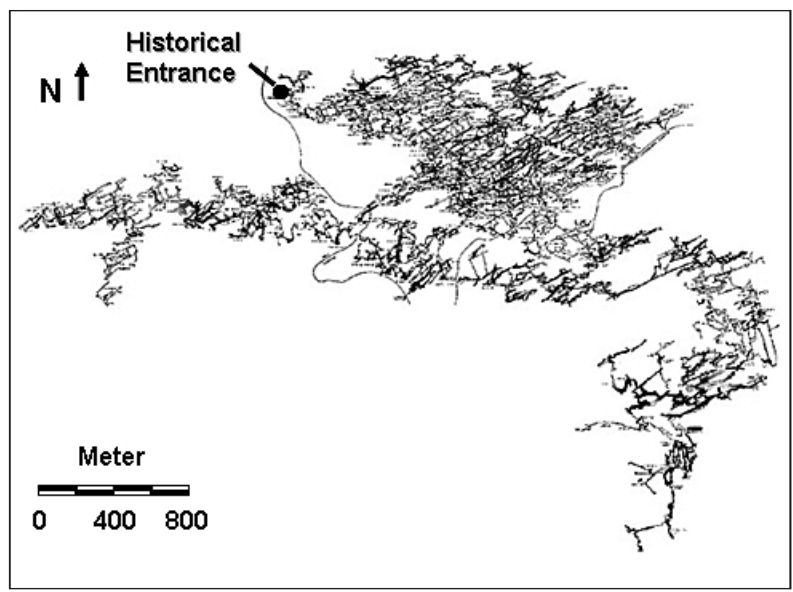

Fig. 8: Outline of Jewel Cave, South Dakota (USA). Reference: Jewel Cave National Monument, with own additions.

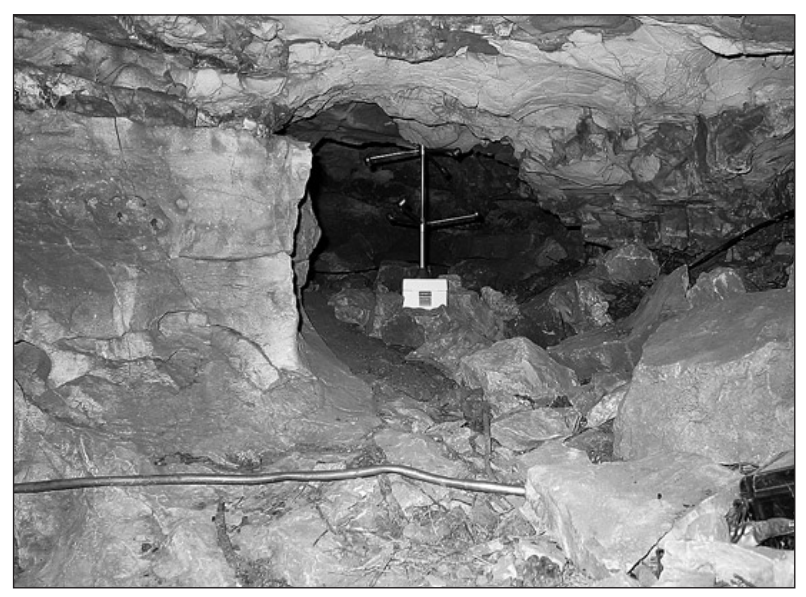

Fig. 10: Sonic anemometer in the Natural Entrance Area of Wind Cave, South Dakota (USA) (Photo: A. Pflitsch).

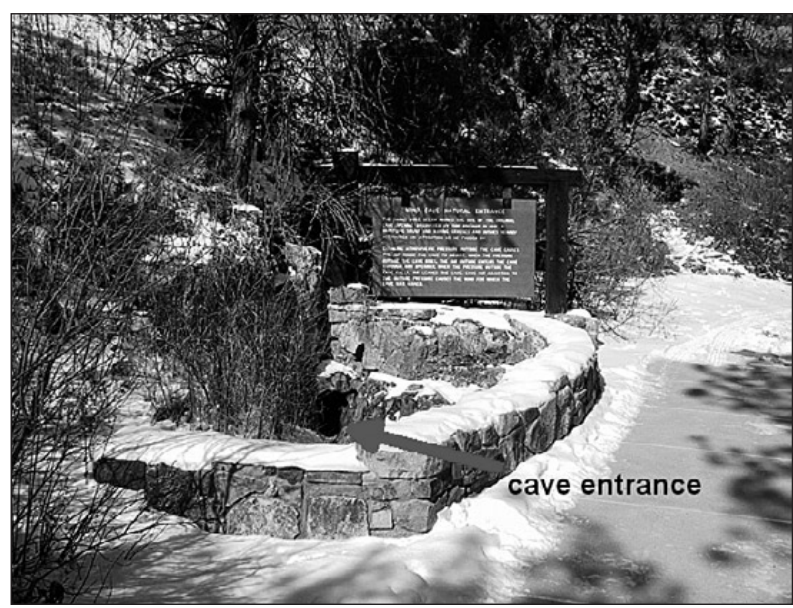

Fig. 7: Natural Entrance of Wind Cave, South Dakota (USA) (Photo: A. Pflitsch).

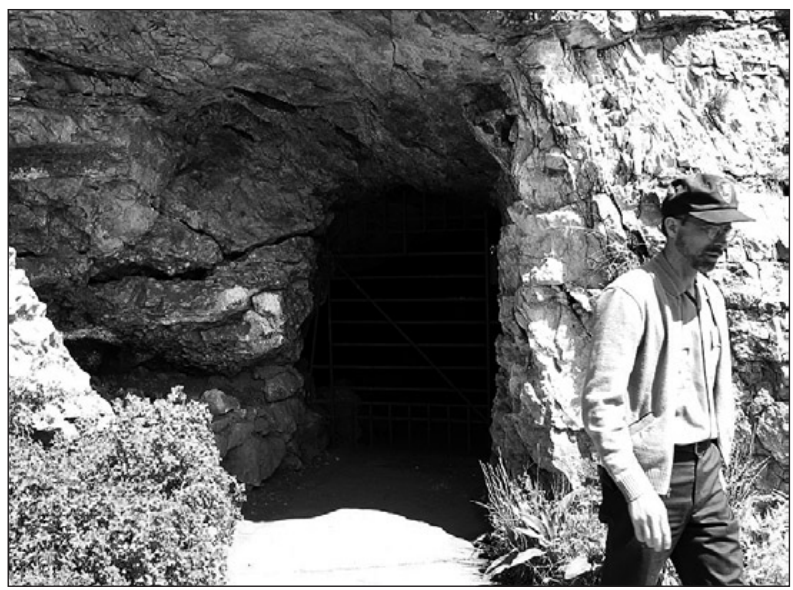

Fig. 9: Historic Entrance of Jewel Cave, South Dakota (USA) (Photo: A. Pflitsch).

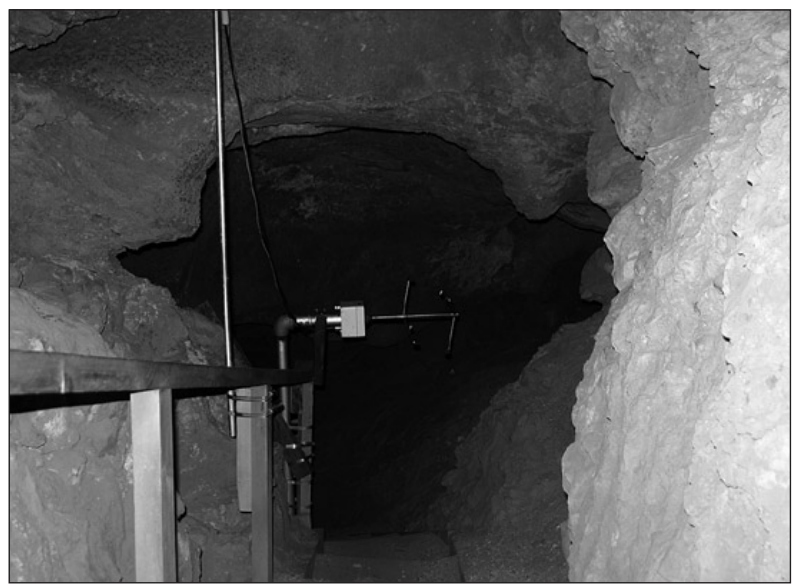

Fig. 11: Sonic anemometer in the Historic Entrance Area of Jewel Cave, South Dakota (USA) (Photo: A. Pflitsch). 


\section{JEWEL AND WIND CAVE}

Each cave system shows a characteristic air flow pattern that depends on the size of the cave and the cave structure, in addition to the weather situation. The more similar the air flow pattern of two cave openings, the higher is the possibility that these belong to the same system.

The first investigations referred to the cave systems of Jewel and Wind Cave, which are considered to be unconnected up to now. Being the second and fourth longest cave systems in the world, each of them forms a huge individual system, though a connection between the caves is being discussed among the local caving clubs and the parks.

Due to the spatial proximity of the two cave systems it was not possible to demonstrate any noticeable differences of the atmospheric pressure gradient in the outside area of the caves. Fig. 12 rather shows an excellent correspondence of the two atmospheric pressure curves. The general form of the graphs is almost identical. There are only marginal deviations of $<1.0 \mathrm{hPa}$.

ing of Wind Cave reacts almost directly to any pressure change, while at the entrance of Jewel Cave this reaction is either distinctly delayed or when pressure changes are small the direction of air flow is not changing at all. Here the periods with consistent air flow direction are much longer.

The same applies for the flow events in March 2005. As Fig. 12 before, Figs. 13, 14 and 15 show similarities and differences of the two flow regimes. They show the air flow velocity in $\mathrm{dm} / \mathrm{s}$ and the direction of air flow for each cave. The direction of air flow is visible from the direction of the graph in relation to the zero line. Numbers $>0 \mathrm{~m} / \mathrm{s}$ mean air flow is streaming out of the cave; numbers $<0 \mathrm{~m} / \mathrm{s}$ relate to ingoing air flow. Each time the graph passes zero again indicates that the direction of air flow has changed. The distance of the graph from the zero line stands for the air flow velocity. The basic patterns of inflow and outflow match with each other over the course of the month as expected. Eventually almost every change in air flow velocity proceeds more or less identically in both caves. However a closer ex-

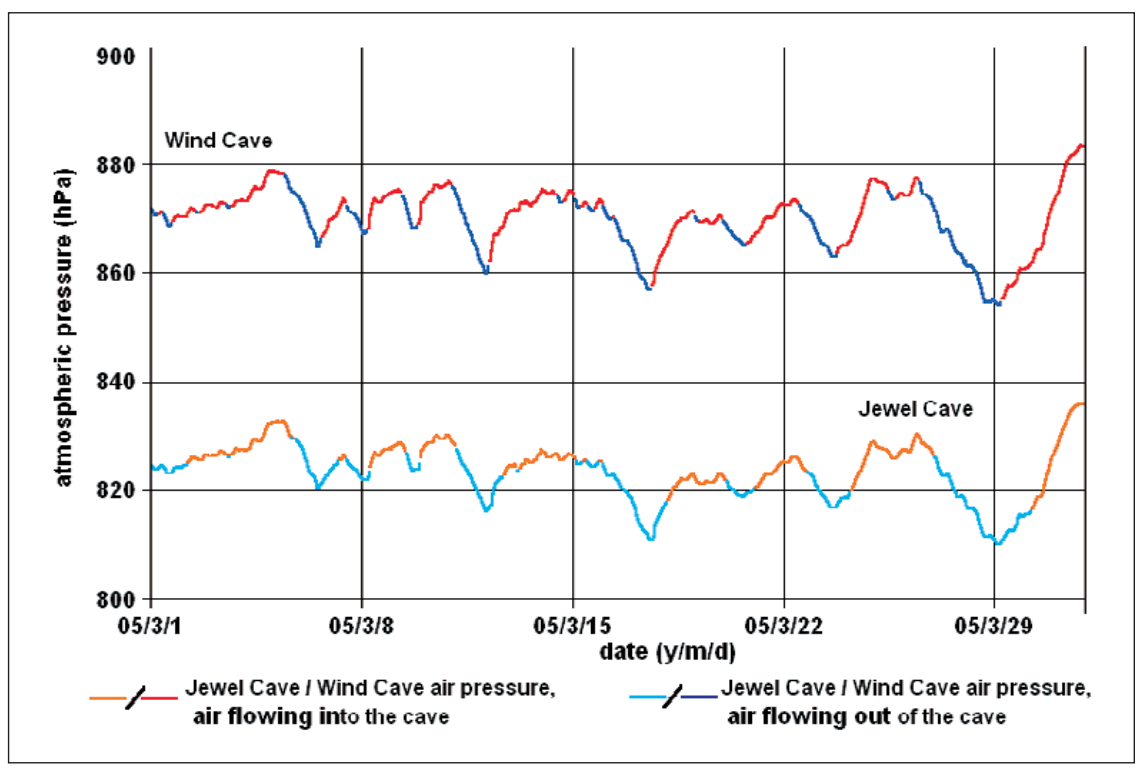

Fig. 12: Course of atmospheric pressure at Jewel Cave and Wind Cave in relationship to the air flow direction at the entrances of the two caves, March 2005.

Only the differences in air pressure are clearly visible. They are caused by the altitude differences (approx. $300 \mathrm{~m}$ ) of the surface openings in both systems. Derived from this it could be assumed that air flow events are identical in the entrance areas of both systems; inflow with increasing air pressure and outflow with decreasing pressure outside. This could not be verified, as shown by the marking of times when air is flowing in and out at the particular pressure lines. It becomes clear that the air flow at the surface openup to $1 \mathrm{~m} / \mathrm{s}$ every minute. amination shows clear modifications. Although slight variabilities in flow velocity can be reproduced identically, they are not connected with a change in air flow direction in both caves. Thus in Fig. 13 one can recognise a transition from an outflow to an inflow-situation and back to an outflow-situation during the first five days of the month in Jewel Cave. During two days the air flows full-time in and out respectively, and the longest period without a change in direction is almost 46 hours. However in Wind Cave changes in direction happen every day, and the longest period of a constant flow direction is only 17 hours.

Looking at Fig. 14 it becomes obvious that the changes from longer outflow- to inflow-situations happen with a distinct time delay (13 hours at 17-18 March) and sometimes only incompletely (12 March) in Jewel Cave. In the contrary case (changes from inflow to outflow), the points in time match considerably better. It also becomes apparent that the flow curve of Wind Cave runs relatively stably and without considerable fluctuations in speed. The flow events in Jewel Cave on the other hand are characterised by strong variations in speed of 

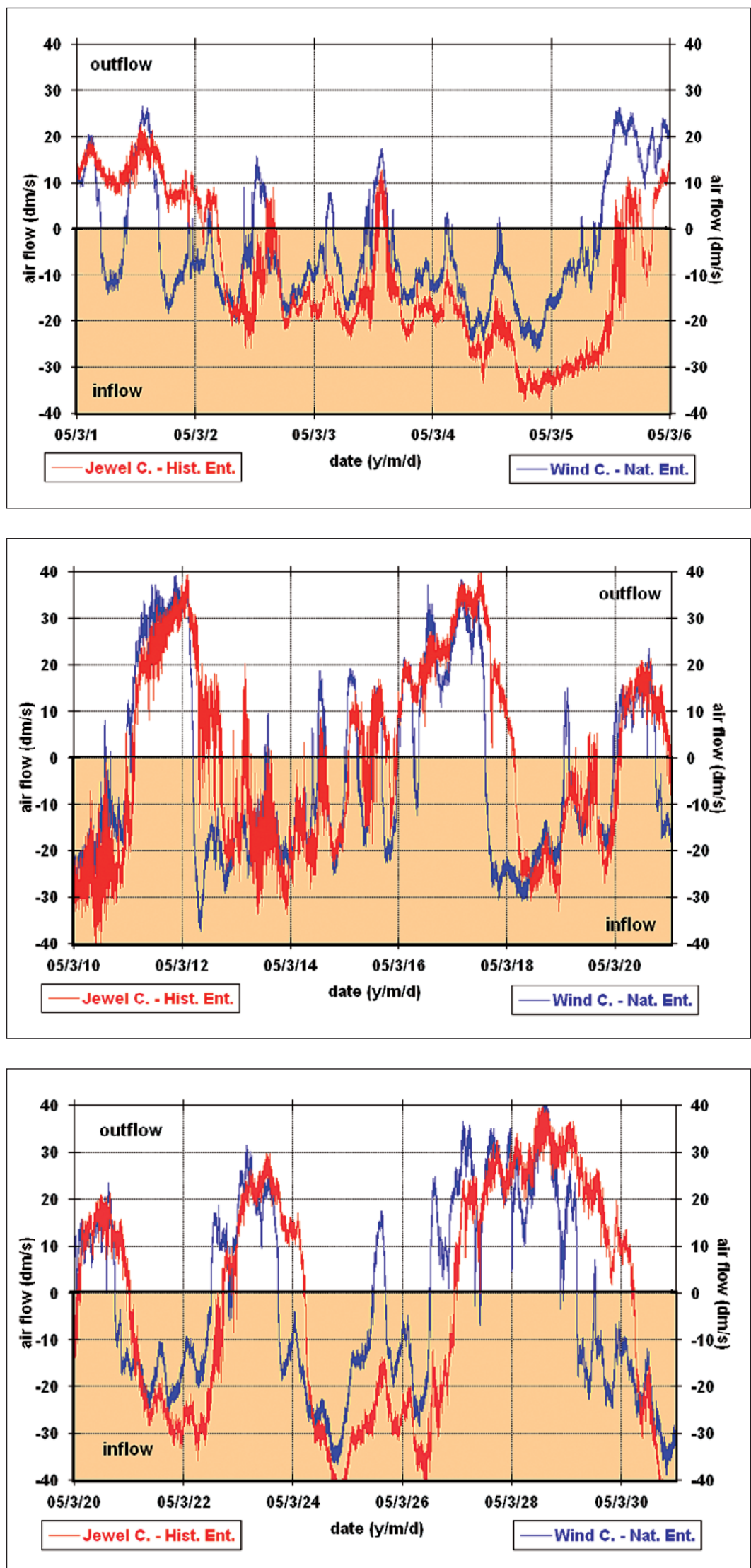

Fig. 13: Course of air flow direction and velocity at the Historic Entrance of Jewel Cave and at the Natural Entrance of Wind Cave from 1-6 March 2005, measured with an ultrasonic anemometer $(10 \mathrm{~Hz}$ and averaging time of $10 \mathrm{~s})$.

Fig. 14: Course of air flow direction and velocity at the Historic Entrance of Jewel Cave and at the Natural Entrance of Wind Cave from 10-21 March 2005, measured with an ultrasonic anemometer $(10 \mathrm{~Hz}$ and averaging time of $10 \mathrm{~s}$ ).

Fig. 15: Course of air flow direction and velocity at the Historic Entrance of Jewel Cave and at the Natural Entrance of Wind Cave from 20-31 March 2005, measured with an ultrasonic anemometer $(10 \mathrm{~Hz}$ and averaging time of $10 \mathrm{~s}$ ). 
Apart from the rare changes in direction, a time delay between changes of outflow and inflow can be noticed during the time displayed in Fig 15. For the shown examples the time delay is 5, 12 and 24 hours, while it is only 1,5 and 10 hours when changing from inflow to outflow. In this context it becomes clear that the dimension of the time delay is a function of the duration of the preceding flow situation. This fact suggests that two systems with different volumes of air are existent, where Jewel Cave must possess a greater air volume due to its delayed reaction. This also explains the overall rare changes in direction. There are numerous short-term micro fluctuations of flow velocity which can not however be attributed to differences in volume. Here the different structures of the openings and the cavities lying behind play a decisive role. Behind the natural entrance the cave system of Wind Cave is very compact and structured like a big sponge. In contrast the area behind the historic entrance of Jewel Cave is characterised by a long conduit system where the pressure fluctuations appear retarded. Further differences and similarities of the caves are not further elaborated here. They are described in detail in Pflitsch et al. (2007).

On closer examination of all figures it becomes apparent that the air is flowing in and out over a long time period at both caves, whereas the periods of outflow are considerably longer at Jewel Cave than at Wind Cave. This assumption is being confirmed by statistics about periods of inflow and outflow in March 2005. Thus during $54 \%$ of the month air is flowing into Jewel Cave and during $46 \%$ air is flowing out. At Wind Cave the proportion is more unequal. Here air is flowing in during 63\% of the time and flowing out only during $37 \%$ of the time. So there are considerable differences we have to study more deeply.

\section{CONNECTION BETWEEN THE CAVE SYSTEMS}

In the surroundings as well as between the two cave systems there are many more small cave systems whose cave climates are verifiably of barometric origin. Those are, for example, S \& G Cave, Jasper Cave, Reeds Cave, Onyx Cave and Coyote Cave (see Fig. 1). Apart from that there are many small blow holes of a size of a few centimetres where the air flow is also barometric. The location between the two big systems and the partial direct proximity make it seem very unlikely - although not impossible - that there are more independent cave systems in addition to the two big systems. ${ }^{4}$ Thus the question comes up

${ }^{4}$ Here it must be pointed out that for a barometric cave a big system is necessary. whether the smaller systems and blowholes can be attributed to the two known caves and whether there are one or more systems that are unknown so far.

In order to solve this problem some considerations were made in advance.

- In a cave system there is a definite volume of air, which is constant if the cave morphology is stable.

- While air is flowing in and out the volume is not changing, but the pressure of the air volume and its compression, respectively, are changing. When air is flowing in, the present air volume is being compressed; when air is flowing out it is being decompressed.

- Based on a pressure balance (which could never be verified in reality) a pressure gradient develops if the outside pressure changes. This pressure gradient aims to balance the air flows towards lower pressure. Therefore air flows into the cave if the outside pressure is rising.

- Based on the consideration that the air pressure above a cave system is equal and that there is a big, connected, balloon like air volume inside the cave, it is totally irrelevant if a volume of air inside the cave is influenced by one or more surface openings.

- A change has the same effect through all openings, meaning that with rising outside pressure the air will flow in through all openings, and from the sides the existing air volume is being compressed. In an area with big and numerous openings it is in the long term and medium term impossible that the inflow of air causes a bigger air volume that leads to a higher pressure pressing the air out of the system at the opposite side. For this to happen the inside pressure would have to rise above the outside pressure, which is physically impossible.

- An exception to the proposition named above can only occur if different surface openings show local variations in the outside pressure, for example caused by a thunderstorm, far distances or bad connections leading to a delayed or independent reaction. Another exception would be the time very close to the pressure equilibrium ${ }^{5}$; here effects like a Helmholtz resonance can take place. Because of the elasticity of the air inside the cave the vibration of the air in and close to the opening or at a transition between a conduit and a big room may cause short airflow effects, with an inflow at one and an outflow at another opening.

\footnotetext{
${ }^{5}$ All our measurements have shown that an equilibrium between the outside pressure and the pressure inside the cave hardly ever lasts longer than a few seconds, but there are periods where the differences are very small with a permanent change of in- and outflow at a very low velocity level. But even here the different entrances react mostly the same.
} 

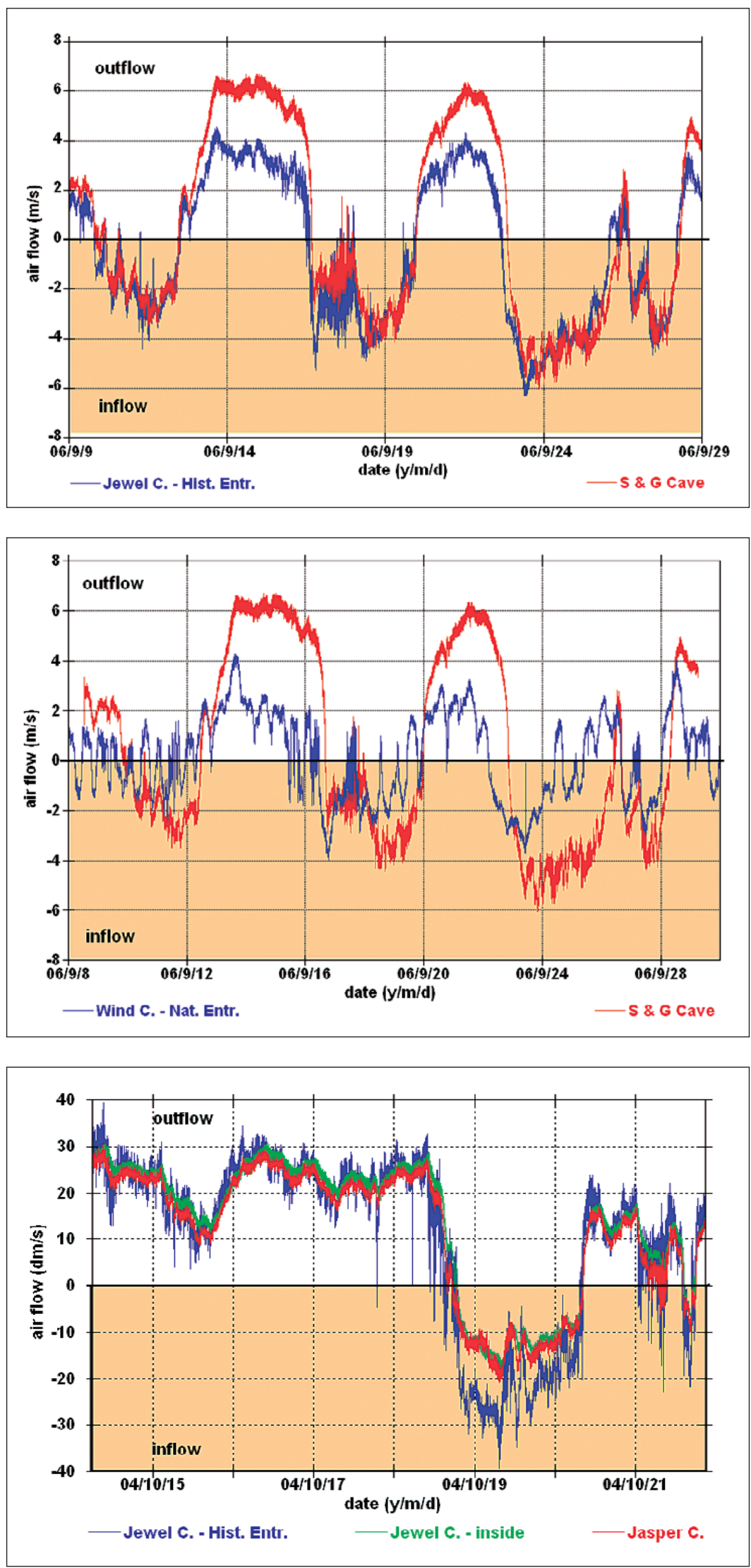

Fig. 16: Comparison of direction of air flow and velocity at the entrances of Jewel Cave and $S$ \& $G$ Cave. Measured from 6-30 September 2006 with an ultrasonic anemometer (10 $\mathrm{Hz}$ and averaging time of $15 \mathrm{~s}$ ).

Fig. 17: Comparison of direction of air flow and velocity at the entrances of Wind Cave and $S$ \& $G$ Cave. Measured from 6-30 September 2006 with an ultrasonic anemometer (10 $\mathrm{Hz}$ and averaging time of $15 \mathrm{~s}$ ).

Fig. 18: Comparison of direction of air flow and velocity at the entrance areas of Jewel Cave and Jasper Cave. Measured from 14-22 October 2004 with an ultrasonic anemometer (10 Hz and averaging time of $15 \mathrm{~s}$ ). 
- This leads to the conclusion that the air must usually flow into the same direction at all openings of a cave system due to barometric influence.

We have used ultrasonic anemometers (Pflitsch \& Piasecki 2003) to find out which of the smaller caves are connected to the bigger caves. Therefore we measured the air flow at each entrance.

Figs. 16 and 17 show results of air flow measurements at $S \&$ G Cave in comparison to the results at Jewel and Wind Cave. Fig. 16 shows that there is a very strong relation between the structure of air flow change at S \& G Cave and Jewel Cave. However, the direction of air flow at Wind Cave (Fig. 17) is clearly different from that at $S \&$ G Cave. Those similarities and differences can be seen from the number of changes and the simultaneity of the air flow changes. In particular, changes in direction for long-term and distinctive air flow situations correspond very well at Jewel and S \& G Cave. Compared to that, Wind Cave and $S \&$ G Cave show large differences.

The small differences in air flow at $S \& G$ and Jewel Cave can be explained by the size and structure of the caves. The large similarities in air flow patterns of those two caves indicate very strongly that they belong to the same big cave system. The same correspondence has been found for Jewel and Jasper Cave (Fig. 18). Interestingly, here the air flow pattern in the entrance of Jasper Cave does match much better to the air flow pattern inside Jewel Cave than to the flow at the Historic Entrance of Jewel Cave.

\section{FINAL EVALUATION OF THE MEASUREMENT RESULTS}

The results of the measurement campaigns at the different caves of the Black Hills, from which we have shown a selected number above, can be summarised as follows:
Extent of the cave systems:

- The extent of the Jewel Cave System is from at least Jasper Cave in the northeast up to S \& G Cave and even Reed's Cave in the southeast. Therefore the cave system is much bigger than the morphological unit known so far. These results are in good agreement with the volume calculations of at least 400,000,000 $\mathrm{m}^{3}$.

- The Wind Cave system is also bigger than until now assumed. The surrounding blow holes can be assigned to this system. The Coyote Cave in the east - even when it is in another geological formation - seems to be part of the Wind Cave too, with less clear signals. From a climatic point of view the changing groundwater level seems to partly separate the two caves.

- A connection between Jewel and Wind Cave could not be demonstrated yet. The air flow patterns partly differ from each other, indicating two separate cave systems, but that does not mean that there is no connection. However, it might be possible that the distance between the two systems is too immense and the connection too small to get a climatically-similar reaction.

- The above explained connection of individual caves, that could be concluded on the basis of air flow patterns, is supported by calculations of air mass balances of the in- and outflowing air at the main openings of the two cave systems, which suggests that both caves must be much larger than is known today.

- Not all of the results can be presented here; besides the differences regarding the air flow regime, pronounced differences concerning the temperature distribution at different openings of the caves could be detected. These will have to be discussed on another occasion.

- Further research will enable the real extent of both cave systems to be established.

\section{ACKNOWLEDGEMENTS}

We thank the DFG (German Research Association) for financial support. Without this, many of the measurements would not have been possible. Furthermore, we are grateful to the management of Jewel Cave National Monument and Wind Cave National Park. They generously enabled us to perform an unrestricted measurement campaign and helped us with some constructional and technical changes of the infrastructure. Our personal thanks goes to Rene \& Mark Ohms, Jason Walz, Andy Armstrong, Markus Brüne, Michael Killing-Heinze, Ben Steiling \& David Holmgren and several students of the Department of Geography, Ruhr-University of Bochum. Without them this project would not have been possible. 


\section{REFERENCES}

Boes, C., Ek, C., Kies, A., Massen, F., Schintgen, G., Sinner, E. \& G. Waringo, 1997: The Moestroff Cave, A Study on the Geology and Climate of Luxembourg's Largest Maze Cave.- Centre de Recherches Public Centre Universitaire, pp. 200, Luxembourg.

Bögli, A., 1978: Karsthydrographie und physische Speläologie.- Springer, pp. 292, Berlin.

Conn, H.W., 1966: Barometric wind in Wind and Jewel Caves, South Dakota.- National Speleological Society Bulletin, 28, 2, 55-69.

National Park Service, 2007a: Jewel Cave National Monument, South Dakota.- [Online] Available from: http://www.nps.gov/jeca [Accessed 15 ${ }^{\text {th }}$ February 2007].

National Park Service, 2007b: Wind Cave National Park, South Dakota.- [Online] Available from: http:// www.nps.gov/wica/naturescience/cave.htm [Accessed $15^{\text {th }}$ February 2007].

Luetscher, M. \& P.Y. Jeannin, 2004: The role of winter air circulation for the presence of subsurface ice accumulation: an example from Monlesi ice cave (Switzerland).- Theoretical and Applied Karstology, 17, 19-25.
Moore, G.W. \& G.N. Sullivan, 1964: Speleology - the study of caves.- Zephrus Press, pp. 150, Teaneck, NJ, USA.

Nepstad, J. \& J. Pisarowicz, 1989: Wind Cave, South Dakota: Temperature and humidity variations.- NSS Bulletin, 51, 125-128.

Palmer, A. N., 2007: Cave Geology.- Cave Books, pp. 454, Dayton, OH, USA.

Pflitsch, A. \& B. Flick, 2000: Proof and characterization of slowest air currents using sonic anemometers in urban and topographical climatology research.Sensors, the journal of applied sensing technology, $17,9,75-82$.

Pflitsch, A. \& J. Piasecki, 2003: Detection of an airflow system in Niedźwiedzia (Bear) Cave, Kletno, Poland.- Journal of Cave and Karst Studies, 65, 3, 160173.

Pflitsch, A., Piasecki, J. \& J. Ringeis, 2007: Untersuchungen zur Klimatologie barometrischer Höhlen am Beispiel von Jewel Cave und Wind Cave in Süd Dakota, USA.- In: Verein für Höhlenkunde in Westfalen (ed.) Speläologisches Jahrbuch 2005/06. pp. 99-112, Iserlohn. 